\title{
The Microbiome of a Shell Mound: Ancient Anthropogenic Waste as a Source of Streptomyces Degrading Recalcitrant Polysaccharides
}

Luciano Huergo ( $\square$ luciano.huergo@gmail.com )

Universidade Federal do Paraná - Campus Centro Politécnico https://orcid.org/0000-0002-7587-9510 Marcelo Conzentino

UFPR: Universidade Federal do Parana

Maria V. Gonçalves

UFPR: Universidade Federal do Parana

Marcos V. Gernet

UFPR: Universidade Federal do Parana

Rodrigo A. Reis

UFPR: Universidade Federal do Parana

Fábio 0. Pedrosa

UFPR: Universidade Federal do Parana

Valter A. Baura

UFPR: Universidade Federal do Parana

Araceli Pires

UFPR: Universidade Federal do Parana

Edileusa C. M Gerhardt

UFPR: Universidade Federal do Parana

Thalita R. Tuleski

UFPR: Universidade Federal do Parana

Eduardo Balsanelli

UFPR: Universidade Federal do Parana

Dieval Guizelini

UFPR: Universidade Federal do Parana

Emanuel M. Souza

UFPR: Universidade Federal do Parana

Govind Chandra

John Innes Institute: John Innes Centre

Leonardo M. Cruz

UFPR: Universidade Federal do Parana 


\section{Research Article}

Keywords: biodiversity, 16S sequencing, Streptomyces, hydrolase

Posted Date: July 8th, 2021

DOl: https://doi.org/10.21203/rs.3.rs-661003/v1

License: (c) (i) This work is licensed under a Creative Commons Attribution 4.0 International License. Read Full License

Version of Record: A version of this preprint was published at World Journal of Microbiology and Biotechnology on November 1st, 2021. See the published version at https://doi.org/10.1007/s11274-02103174-4. 


\section{Abstract}

Metagenome amplicon DNA sequencing and traditional cell culture techniques are helping to uncover the diversity and the biotechnological potential of prokaryotes in different habitats around the world. It has also had a profound impact on microbial taxonomy in the last decades. Here we used metagenome $16 \mathrm{~S}$ rDNA amplicon sequencing to reveal the microbiome composition of different layers of an anthropogenic soil collected at a shell mound Sambaqui archeological site. The Samabaqui soil microbiome is mainly composed by phyla Acidobacteria, Rokubacteria, Proteobacteria and Thaumarchaeota. Using culturedependent analysis we isolated few Streptomyces strains from the Sambaqui soil. One of the isolates, named Streptomyces sp. S3, was able to grow in minimal medium containing recalcitrant polysaccharides including chitin, xylan, carboxymethylcellulose or microcrystalline cellulose as sole carbon sources. The activities of enzymes degrading these compounds were confirmed in cell free supernatants. The genome sequence revealed not only an arsenal of genes related to polysaccharides degradation but also biosynthetic gene clusters which may be involved in the production of biotechnologically interesting secondary metabolites.

\section{Introduction}

Microbiomes constitute an important source for the prospection of industrially relevant enzymes and bioactive metabolites such as antibiotics or chemotherapeutic drugs. For instance, most of the antibiotics used in the clinics nowadays are still the fruits of valuable prospection of Streptomyces strains from the environment, mostly from soil (Liu et al., 2013).

The recent advances in metagenomic $16 \mathrm{~S}$ rDNA amplicon sequencing and whole metagenome DNA sequencing is helping to uncover the microbial diversity and their biotechnological potential at an unprecedent scale (Nayfach et al., 2020; Thompson et al., 2017). Global efforts such as the earth's microbiome is providing valuable data on how microbial diversity is distributed around the globe and how microbial taxa correlate in similar environments in distant locations (Stevens et al., 2017). In addition to these high-tech platforms, microbial diversity can be accessed using traditional culture isolation techniques. Quite remarkably, traditional methods are still very effective in the discovery of novel bacterial strains with biotechnological potential (Wilson et al., 2014).

Brazil hosts a significant portion of the world's biodiversity and the Brazilian territory constitute an untapped source for the prospection of novel microbes. Still, most of the Brazilian biomes are only marginally explored in terms of microbiome composition (Pylro and Roesch, 2017). Our research group is combining metagenomics and traditional cell culture techniques to uncover the microbiome in yet to be explored Brazilian environments such as the pristine Amazon forest air (Souza et al., 2019) and the mangrove soil (Huergo et al., 2018).

Mangroves are particularly interesting habitats for microbial prospection, given the unique chemical characteristics and diel tidal variations which affect salinity, oxygen, $\mathrm{pH}$ and nutrient availability (Alongi, 
2014). Nevertheless, there are very few studies on Brazilian mangrove microbiome (Andreote et al., 2012; Ceccon et al., 2019; Huergo et al., 2018; M. and R., 2020; Mendes and Tsai, 2018).

The high primary productivity of mangrove estuaries provides plenty of availability of sea food. Not surprisingly, mangrove estuaries were colonized by ancient groups of fisher-hunters-collectors, vestiges of these ancestral human activities are preserved in several archaeological sites on the coast of Brazil which are named Sambaqui sites (Okumura \& Eggers, 2005; Gernet et al., 2014). Sambaqui sites consist mostly of molluscs' shells which are likely to be the waste products of meals eaten by groups of hunter-fisherscollectors that lived in the area between 2,000-10,000 years ago (Scheel-Ybert, 2001). The Sambaqui anthropogenic soil are typically arranged in layers with varying composition that are likely to reflect the occupation of these sites by different groups (Fig. 1), with the bottom layers representing the debris of the most ancient groups.

Given their unique characteristics the Sambaqui sites constitute unique niches which may host interesting uncharacterized microbes. Here we used 16S rRNA gene amplicon sequencing and culture techniques to provide the first microbiome description of an anthropogenic Sambaqui soil, namely the Sambaqui Bogaçu, located in Guaratuba, south of Brazil. One isolated bacterial strain from this site, named Streptomyces sp. S3, showed interesting biotechnological properties including the ability to degrade recalcitrant polysaccharides such as chitin, xylan, carboxymethyl cellulose and microcrystalline cellulose. Hence, Streptomyces sp. S3 has potential applications in biofuel production from lignocellulose waste products. A draft genome of Streptomyces sp. S3 was obtained showing an arsenal of putative polysaccharides hydrolytic enzymes. Furthermore, several biosynthetic gene clusters were identified in the Streptomyces sp. S3 genome revealing that this strain may have the ability to produce important biotechnological secondary metabolites.

\section{Material And Methods}

\subsection{Sampling and culturable bacteria analysis}

The Sambaqui Boguaçu is located at the margin of the Boguaçú river in a place called llha do Casqueiro, Guaratuba Bay estuary, Paraná, Brazil ( $\left.25^{\circ} 55^{\prime} 11^{\prime \prime S ~ / ~} 48^{\circ} 37^{\prime} 39^{\prime \prime} \mathrm{W}\right)$. This Sambaqui is $7 \mathrm{~m}$ high and is likely to date between 10,000 and 2,000 years ago (Huergo et al., 2018) (Fig. 1). Samples were collected in a dry region of the site not subject to sea tide or river flooding. Samples were retrieved from three visually different stratification profiles of the Sambaqui layers, namely samples $B, C M$ and $S$, from bottom to top, respectively (Fig. 1). About $2 \mathrm{~g}$ of sediment were removed from $\sim 15 \mathrm{~cm}$ within the interior of Sambaqui profile using a sterile spoon. Samples were immediately stored in a sterile tube. Approximately one hour after sampling, $1 \mathrm{~g}$ sample of the sediment was diluted with $9 \mathrm{ml}$ of sterile saline ( $10^{-1}$ dilution), vortexed for $5 \mathrm{~min}$ and allowed to stand for 5 minutes for dense material to settle down. The supernatant was used to prepare a $10^{-2}$ dilution in saline, of which $100 \mu$ were spread on LB agar containing cyclohexamide $50 \mu \mathrm{g} \cdot \mathrm{ml}^{-1}$ to inhibit the growth of fungi. Plates were incubated aerobically at 
$30^{\circ} \mathrm{C}$ for 5 days. The colonies developed were further replicated and stored in glycerol $50 \%$ at $-20{ }^{\circ} \mathrm{C}$ at the culture collection of Setor Litoral, Federal University of Parana (UFPR), Matinhos - PR, Brazil.

Some isolates were subjected to partial 16S rRNA gene sequencing as described previously (Stets et al., 2013). Isolates were taxonomically identified by comparing the DNA sequences against the $16 \mathrm{~S}$ ribosomal RNA gene sequences (Bacteria and Archaea) database at NCBI, using blastn (Altschul et al., 1990). All sequences were deposited in GenBank under the accession numbers MT019671, MT019672, MT019673 and MT019674.

\subsection{Total DNA extraction and 16S rRNA gene amplicon Illumina sequencing}

Total DNA extraction from the three Sambaqui soil layers were performed using Power Soil DNA Kit (MOBIO). The DNA recovered from the kit was precipitated with ethanol $80 \%$, dried and all the genetic material was used as template for PCR amplification as described previously (Souza et al., 2019). Briefly, the $V 4$ region of the $16 \mathrm{~S}$ gene was PCR amplified in $10 \mu$ l reactions using: all dried template DNA; $1 \mu \mathrm{M}$ primer 515F; $1 \mu \mathrm{M}$ primer 806R (which includes the barcode for each sample); and $5 \mu \mathrm{l} \mathrm{KlenTaq} \mathrm{DV}$ ReadyMix (Sigma-Aldrich). The PCR cycles were $94^{\circ} \mathrm{C} 3 \mathrm{~min}, 18 \mathrm{x}\left(94^{\circ} \mathrm{C} 45 \mathrm{~s}, 50^{\circ} \mathrm{C} 30 \mathrm{~s}, 68^{\circ} \mathrm{C} 1 \mathrm{~min}\right), 72^{\circ} \mathrm{C}$ $10 \mathrm{~min}$. Amplicons were sequenced in a MiSeq platform using MiSeq 500v2 Reagent Kit (Illumina) pairend reads $(2 x$ of $250 \mathrm{bp})$.

Sample sequences were imported and demultiplexed in QIIME2 (Bolyen et al., 2019), then inputted into the plugin DADA2 (Callahan et al., 2016) on QIIME2 to filter low-quality data, denoising sequences, remove chimeras, join forward and reverse reads, and dereplicate sequences in amplicon sequence variants (ASV). After all steps, non-chimeric sequences were generated and reduction in sequence numbers per samples were observed as follow: sample B, from 45,305 to $30,874(31,8 \%)$ and sample $S$, from 133,303 to 108,230 (18,8\%). A naïve Bayesian classifier was used through q2-feature-classifier QIIME2 plugin to classify sequences against a pre-trained classifiers on SILVA v.128 16S rRNA 515F/806R gene-region database clustered at 99\% identity (Pedregosa et al., 2011; Quast et al., 2013), available at https://docs.qiime2.org/2020.11/data-resources (MD5: 28105eb0f1256bf38b9bb310c701dc4e). The 16S rDNA amplicon sequences were deposited in NCBI study numbers PRJNA605351, SRS6116179 and SRS6116180.

\subsection{Screening for Bacteria isolates that degrade recalcitrant polysaccharides}

Isolates were tested for the ability to grow in solid agar M9 minimum medium (Green et al., 2012) containing ammonium chloride $20 \mathrm{mM}$ as nitrogen source and $1 \%(\mathrm{w} / \mathrm{v})$ of glucose, xylan, colloidal chitin, carboxymethyl cellulose or cellulose microcrystalline as carbon sources. Control agar plates without extra carbon source was also used to evaluate the ability of the isolates to use agar as carbon source. Isolates were streaked on M9 media plates and incubated for 5 days at $30^{\circ} \mathrm{C}$. The ability to use each carbon source was based on the visual inspection of the amount of biomass after 5 days at $30^{\circ} \mathrm{C}$. 
The ability to degrade xylan, colloidal chitin and carboxymethyl cellulose was confirmed by the formation of degradation halo after staining the plates with congo red $0.1 \%(\mathrm{w} / \mathrm{v})$ and de-staining with $\mathrm{NaCl} 1 \mathrm{~mol} / \mathrm{l}$.

To confirm the ability of Streptomyces S3 to degrade recalcitrant polysaccharides, one isolated colony from LA medium was inoculated into $200 \mathrm{ml}$ of M9 liquid medium containing xylan, carboxymethyl cellulose, microcrystalline cellulose or filter paper $1 \%(\mathrm{w} / \mathrm{v})$ as sole carbon source. The flasks were incubated for 7 days in a rotary shaker at $30^{\circ} \mathrm{C}$ and $120 \mathrm{rpm}$. Bacterial growth was accessed by visual inspection of bacterial biomass, by staining the cell-substrate matrix clumps for protein with Bradford reagent and/or by electronic microscopy analysis of the cell-substrate matrix clumps. To verify the presence of secreted hydrolytic enzymes, the supernatant was separated from the cells and insoluble substrates by centrifugation at $5,000 \mathrm{xg}$ for $10 \mathrm{~min}$. A fraction of $10 \mu \mathrm{l}$ of the supernatant was spotted onto a plate containing solid agar M9 medium with $1 \%(\mathrm{w} / \mathrm{v})$ xylan or carboxymethyl as substrate. After incubation at $30^{\circ} \mathrm{C}$ for 30 min enzymatic activity was confirmed by the formation of degradation halo after staining the plates with congo red.

\subsection{Scanning electron microscopy}

The samples were fixed with $2 \%$ paraformaldehyde, dehydrated in ascending ethanol series, and the critical point was reached in a Bal-Tec CPD - 030 with carbon dioxide. The gold plating was obtained in a Balzers SCD-030. SEM analysis were performed in a scanning electron microscope JEOL-JSM $6360 \mathrm{~L}$ at the Electron Microscopy Center of UFPR, Curitiba, PR. Brazil.

\subsection{Genome sequencing and analysis}

Total DNA extraction from the isolate Streptomyces sp. S3 were obtained from cells cultured in LB agar medium and extracted using Power Soil DNA Kit (MOBIO). The whole-genome sequence was carried out using Nextera DNA Library Preparation Kit and paired-end sequencing in the Illumina MiSeq platform. Raw reads quality was checked by FastQC (Andrews, 2010). DNA sequence was de novo assembled using Spades (Bankevich et al., 2012). The draft genome was annotated using Prokka (Seemann, 2014) and RAST (Overbeek et al., 2014). The draft genome sequence assembly was deposited in NCBI Assembly database under the identifier ASM1304450v1. Genome blast phylogeny was directly retrieved from NCBI.

The identification of carbohydrate-active enzymes were performed by comparing the Proteome of Streptomyces sp. S3 against the latest (available on January 2020) CAZy database (Cantarel et al., 2009) using BlastP (Altschul et al., 1990). Proteins were considered as putative carbohydrate-active enzymes when the alignment score with a CAzy database entry had evalue $\leq 5^{-100}$ and the fraction of hit (CAZy) covered in the alignment was $\geq 0.4$. Analysis of secondary metabolite biosynthesis gene clusters were performed using antiSMASH (Blin et al., 2019) and phylogenetic analysis were performed using autoMLST (Alanjary et al., 2019).

\subsection{Cell culture collection deposit}


The strain Streptomyces sp. S3 was deposited at CMRP WDCM1240 - Microbiological Collections of Paraná Network - Federal University of Parana at code number CMRP5229.

\section{Results}

In this study we focused on an archaeological Sambaqui site located in the Boguaçú River which is part of the Guaratuba bay estuary (Fig. 1). The soil of the Sambaqui Boguaçú is arranged in three visually distinct layers, with varying composition, that are likely to reflect the time of occupation of this site by different groups (Fig. 1C). To assess the microbial diversity within the Sambaqui-Boguaçú samples of the three visually different layers were collected and subjected to microbial cultivation approach and to metagenome microbial biodiversity survey.

\subsection{Prokaryotic biodiversity using 16S rDNA amplicon sequencing}

Total DNA was extracted from each of the three Sambaqui layers (Fig. 1C). The medium layer, namely $\mathrm{CM}$, did not yield enough DNA for this analysis and was not considered for further analysis. The extracted metagenomic DNA from the top layer, namely S, and the bottom layer, namely B, were used as template for PCR amplification of the V4 region of the 16S rRNA gene and subjected to next generation Illumina sequencing using primers and methodology described previously (Huergo et al., 2018).

The amplicon sequence variants (ASV) were taxonomically classified; $13.8 \%$ and $9.3 \%$ of the ASV were classified as Archaea in S and B samples, respectively. Strikingly, despite being visually different (Fig. 1C), the samples $S$ and $B$ had similar biodiversity profiles at Phylum level (Fig. 2). The most represented Phylum were Acidobacteria, Rokubacteria, Proteobacteria and the Archaea Thaumarchaeota (Fig. 2). The most represented identified family was the methylotrophic Methylomirabilaceae ( $10 \%$ of the reads in both samples) (Figure S1). This family was reported to be abundant in paddy fields, an anaerobic habitat typically rich in methane (Ghashghavi et al., 2019). The Sambaqui site explored in this study was built over a mangrove which is also considered a habitat with high methane production, this may explain the abundance of the methylotrophic Methylomirabilaceae in our samples. Most of the remaining sequences could not be classified at Family (Figure S1) or lower taxonomic levels. These data support that the Sambaqui site hosts unique poorly characterized microorganisms.

\subsection{Bacteria isolation and selection for growth in recalcitrant polysaccharides}

All the three different layers of Sambaqui samples were diluted in saline and the $10^{-2}$ dilution was plated in LB agar medium. The samples from the layers B and CM did not yield any CFU, while sample $S$ produced $8 \mathrm{CFU}$, namely $\mathrm{S} 1$ to $\mathrm{S} 8$. The isolates $\mathrm{S} 3$ and $\mathrm{S} 8$ showed a similar colony morphology and produced of a dark pigment in LB agar plates or LB liquid medium (Figure S2). The isolates were evaluated for their ability to growth in M9 minimum medium containing glucose, agar, colloidal chitin, 
microcrystalline cellulose (MCC), carboxymethyl cellulose (CMC) or xylan as carbon sources. All the isolates were able to grow using glucose as carbon source while using ammonium as nitrogen source (Table 1). Interestingly, the isolates S3 and S8 showed little growth in M9-glucose agar plates without a nitrogen source (Table 1). Furthermore, the isolates S3 and S8 grew well in LB agar prepared using sea water indicating halophilic properties (not shown).

Table 1

Growth of isolates in M9 solid minimum medium with different carbon sources.

\begin{tabular}{|c|c|c|c|c|c|c|c|}
\hline \multirow[t]{2}{*}{ Isolate } & \multicolumn{7}{|c|}{ Carbon Source $^{1}$} \\
\hline & Glucose & Agar & Chitin & MCC & $\mathrm{CMC}$ & Xylan & Glucose without nitrogen \\
\hline S1 & +++ & - & - & - & - & - & - \\
\hline S2 & + & - & - & - & - & - & - \\
\hline S3 & +++ & + & ++ & + & ++ & +++ & + \\
\hline S4 & + & - & - & - & - & - & - \\
\hline S5 & +++ & - & - & - & - & - & - \\
\hline S6 & +++ & - & - & - & - & - & - \\
\hline S7 & + & - & - & - & - & - & - \\
\hline S8 & +++ & + & ++ & + & ++ & +++ & + \\
\hline
\end{tabular}

The isolates S3 and S8 were able to growth in M9 agar containing different recalcitrant carbohydrates as carbon source including agar, chitin, CMC, MCC and xylan (Table 1 and Figure S3). Given that S3 and S8 were able to grow using agar as sole carbon source, we consider that the growth detected in the presence of other polysaccharides could be sustained by agar degradation instead. However, the degradation of chitin, $\mathrm{CMC}$ and xylan could be confirmed by staining the agar plates with congo red which showed typical polysaccharide degradation halo (Figure S3C).

To provide a taxonomic classification for the isolates the $16 \mathrm{~S}$ rRNA gene of the isolates S3, S5, S6, and S8 were PCR amplified and subjected to partial sequencing. All sequences showed $100 \%$ identity to various Streptomyces strains when searched against specialized 16S rRNA NCBI database. Multiple sequence alignment of the 16S rRNA gene revealed two groups of sequences, one includes the sequences of S3 and S8 which were identical in pair wise comparison. The sequences of isolates S5 and S6 were also identical in pair wise comparison. The two different groups of isolates (S3-S8 and S5-S6) showed 4 base differences within the 16S rDNA V4/V5, 98.5\% identity (Figure S4). Despite belonging to Streptomyces genus these two groups of isolates have completely different capacity to use recalcitrant polysaccharides as carbon source in M9 media (Table 1). 
The isolate Streptomyces sp. S3 was subjected to further characterization. This bacterium was able to growth aerobically in M9 liquid medium containing the soluble polysaccharides xylan and CMC as the only carbon source. Streptomyces sp. S3 formed cell pellets in these media (Fig. 3A and B). Scanning electron microscopy analysis of these pellets showed the formation of typical Streptomyces mycelium (Fig. 3). Interestingly, the morphology of the mycelium was different in medium containing xylan or CMC. When using $\mathrm{CMC}$ as carbon source, the mycelium was covered with an apparent extracellular matrix (Fig. 3). We suspect that this cell surface adhering material may be formed by an extracellular complex of $\mathrm{CMC}$ and enzymes involved in $\mathrm{CMC}$ degradation.

Qualitative analyses for presence of active extracellular enzymes degrading xylan and CMC were carried out by placing $10 \mu \mathrm{l}$ of each cell culture supernatant over M9 solid medium containing either xylan or $\mathrm{CMC}$. After $30 \mathrm{~min}$ incubation at $30^{\circ} \mathrm{C}$, the plates were stained with congo red to detect substrate degradation. As expected, degradation of xylan was readily detected using the supernatant of cells cultured in xylan (Figure S5A, spot 1). On the other hand, and quite surprisingly, only a faint CMC degradation halo was detected using the supernatant of cells cultured in CMC (Figure S5A, spot 3). The amount of protein in the culture supernatants were below the limit of detection and could not be determined. Hence, at this point, we cannot infer if the differences in xylan vs $\mathrm{CMC}$ degradation halo are caused by differences in total enzymes load and/or specific enzyme activities.

The ability of Streptomyces sp. S3 to grow aerobically in M9 liquid medium carrying insoluble MCC or filter paper as sole carbon sources was also evaluated. Even though the cells did not appear as pellets as observed when growing with $\mathrm{CMC}$ or xylan, it was possible to confirm microbial biomass development adhered to the insoluble MCC by staining the remaining insoluble substrate for protein using the Bradford reagent (not shown). Furthermore, it was possible to detect active xylan and CMC degrading extracellular enzymes from the Streptomyces sp. S3 supernatant of cells cultured in MCC (Figure S5A, spot 3). The supernatant from MCC growing cells produced a more intense CMC degradation halo than those assayed with the supernatant of cells growing in CMC itself (Figure S5B, compare spots 3 and 4).

\subsection{Genome analysis}

A draft genome sequence of Streptomyces sp. S3 was obtained comprising 569 contigs (40558 N50), with a total of $10,992,946$ bp with $\mathrm{G}+\mathrm{C}$ content of $70.55 \%$. Genome annotation revealed 9844 protein coding sequences. The Streptomyces sp. S3 genome was used to perform phylogenetic analysis against reference organisms using Automated Multi-Locus Species (auto MLST) (Alanjary et al., 2019). The phylogenetic tree revealed that Streptomyces antibioticus DSM40234 is the closet type strain to Streptomyces sp. S3 (Figure S6) with a MASH distance of 0.1064 and estimated average nucleotide identity of 0.8936 (Table S1). S. antibioticus was originally isolated from soil and is well known for its potential to produce several bioactive compounds, including several antibiotics. There are strains of $S$. antibioticus isolated form marine environment which may explain the halophilic properties of the Streptomyces S3 isolate (Sharma et al., 2019; Waksman and Woodruff, 1941; Wang et al., 2017; Xu et al., 2011). Automated genome blast-based phylogeny retrieved from NCBI indicated that soil environmental isolate Streptomyces sp. WM6386 (Blodgett et al., 2016) as the closest relative (Figure S7). 
In order to identify biosynthetic gene clusters (BGC) the Streptomyces sp. S3 genome was subjected to antiSMASH analysis (Blin et al., 2019) which predicted 22 BGCs, totalling 464,995bp (4.2\% of the genome), including: 4 terpene (76,408bp); 1 polyketide synthase (PKS; 32,694bp); 1 polyketide synthase (PKS)/nonribosomal peptide synthetase (NRPS) hybrid (68,067bp); 6 NRPS among other (220,742bp) (Table S2). Out of these, only 5 showed similarities $\geq 0.7$ to known BGC including those involved in the biosynthesis of the terpenes albaflavenone, geosmin, ectoine and hopene. A BGC for melanin production was also found, suggesting that melanin be responsible for the black pigmentation of Streptomyces sp. S3 when cultured in LB medium (Figure S2). Indeed, two putative tyrosinases containing secretion Nterminal signal peptides were identified in the annotated genome (not shown). A BGC involved in ectoine production was identified (Table S2). Ectoine is produced by halophilic and halotolerant microorganisms to prevent osmotic stress in highly saline environments (Reshetnikov et al., 2011). The production of ectoine may explain the halotolerant behavior of Streptomyces sp. S3.

To assess the potential for carbohydrate degradation the predicted proteome of Stremptomyces S3 were compared with the enzymes deposited at the CAZy database using blastP. This analysis revealed a total of 459 enzymes comprising: 247 Glycosyl Hydrolase; 99 Glycosyl transferases; 25 Polysaccharide lyases; 31 Carbohydrate esterases; 5 Auxiliary activity; 121 Carbohydrate-binding modules (Table S3). 214 (46.6\%) of these putative CAZy enzymes were annotated as hypothetical proteins by Prokka while some enzymes were annotated as putative Chitinases, xylanases and cellulases (Table S3). These data provide additional support that Stremptomyces $\mathrm{S} 3$ is well suited for recalcitrant polysaccharide degradation and a potential source of biotechnologically relevant enzymes.

\section{Discussion}

Despite global efforts to uncover the microbial diversity and biotechnological potential there are still untapped sources to explore specially in environments where less sampling efforts were concentrated. In this study we provide the first microbiome analysis of the anthropogenic soil layers of an archeological Sambaqui site located in the South of Brazil. By using metagomic DNA extraction and 16S rDNA amplicon sequencing we identified Acidobacteria ( 19\%), Rokubacteria ( 17\%), Proteobacteria ( $16 \%)$ and Thaumarchaeota $(\sim 9 \%)$ as the most representative phylum in different layers of the Sambaqui soil. Quite remarkably, most of the reads could not be classified at lower taxonomic level suggesting that this site contains unique previously undescribed microbes (Fig. 2 and Figure S1). We have analysed previously the microbiome of the pristine mangrove soil and mangrove soil affected by the eroding debris at this Sambaqui site. The microbiome composition in the mangrove soil at the flooding level was remarkably different with Proteobacteria ( 49\%), Chloroflexi $(\sim 12 \%)$, and Bacterioidetes $(\sim 6 \%)$ being the dominant taxa (Huergo et al., 2018).

Using culture techniques, a low number of CFU was obtained from just one of the soil layers using the rich medium for cell culture (Figure S2). Such poor recovery is likely to reflect the fact that the Sambaqui soil is poor in organic matter despite abundant carbonaceous shell debris. Nevertheless, few Streptomyces could be isolated which may reflect the fact that Streptomyces can survive in dormant 
spores and/or because Streptomyces typically can use a range of substrates as carbon sources including recalcitrant polysaccharides. In fact, the isolated Streptomyces sp. S3 was able to use agar, chitin, CMC, MCC and xylan as carbon sources and showed residual growth even in the absence of a nitrogen source (Table 1). The presence of enzyme degrading recalcitrant polysaccharides was confirmed by assaying the enzymatic activity in cell culture supernatant (Figure S5) and corroborated by genome analysis of Streptomyces sp. S3 (Table S3). Interestingly, several studies on different Streptomyces support that some strains have the ability to degrade cellulosic biomass (Takasuka et al. 2013; Lim et al. 2015; Pinheiro et al. 2017). Studies are under way to identify the enzymes responsible for CMC and MCC degradation in Streptomyces sp. S3.

The genome analysis of Streptomyces sp. S3 indicated that $S$. antibioticus is the closest type strain (Figures S1 and S6). However, the low nucleotide identity ANI suggest that Streptomyces sp. S3 may constitute a novel species. The genome data also support that Streptomyces sp. S3 may produce secondary metabolites of biotechnological importance (Figure S2). This is expected since its closest relative S. antibioticus is a well-known antibiotic producer (Sharma et al., 2019).

\section{Declarations}

Funding This work was supported by CNPq, Fundação Araucária, CAPES and CNPq-INCT of Biological Nitrogen Fixation.

Conflicts of interest/Competing interests Nothing to declare

Availability of data and material Materials and data are available upon request

Code availability Not applicable.

Authors' contributions. L.H, M.C, M.V.G, M.G collected and processed the samples; V.B and E.B processed the samples for Illumina sequencing; E.M.G. and T.T. performed the microscopy analysis; A.P. analyzed microbiome data; L.H, D.G, L.C and G.C analyzed the genome sequence. R.R, L.H, E S, L.C and F.P, project and lab management. L.H wrote the manuscript with inputs form all authors.

\section{References}

1. Alanjary, M., Steinke, K., Ziemert, N., 2019. AutoMLST: an automated web server for generating multilocus species trees highlighting natural product potential. Nucleic Acids Res. https://doi.org/10.1093/nar/gkz282

2. Altschul, S.F., Gish, W., Miller, W., Myers, E.W., Lipman, D.J., 1990. Basic local alignment search tool. J. Mol. Biol. https://doi.org/10.1016/S0022-2836(05)80360-2

3. Andreote, F.D., Jiménez, D.J., Chaves, D., Dias, A.C.F., Luvizotto, D.M., Dini-Andreote, F., Fasanella, C.C., Lopez, M.V., Baena, S., Taketani, R.G., de Melo, I.S., 2012. The microbiome of Brazilian mangrove sediments as revealed by metagenomics. PLoS One. https://doi.org/10.1371/journal.pone.0038600 
4. Andrews, S., 2010. FastQC - A quality control tool for high throughput sequence data. http://www.bioinformatics.babraham.ac.uk/projects/fastqc/, Babraham Bioinformatics. https://doi.org/citeulike-article-id:11583827

5. Bankevich, A., Nurk, S., Antipov, D., Gurevich, A.A., Dvorkin, M., Kulikov, A.S., Lesin, V.M., Nikolenko, S.I., Pham, S., Prjibelski, A.D., Pyshkin, A. V., Sirotkin, A. V., Vyahhi, N., Tesler, G., Alekseyev, M.A., Pevzner, P.A., 2012. SPAdes: A new genome assembly algorithm and its applications to single-cell sequencing. J. Comput. Biol. https://doi.org/10.1089/cmb.2012.0021

6. Blin, K., Shaw, S., Steinke, K., Villebro, R., Ziemert, N., Lee, S.Y., Medema, M.H., Weber, T., 2019. antiSMASH 5.0: updates to the secondary metabolite genome mining pipeline. Nucleic Acids Res. https://doi.org/10.1093/nar/gkz310

7. Blodgett, J.A., Zhang, J.K., Yu, X., Metcalf, W.W., 2016. Conserved biosynthetic pathways for phosalacine, bialaphos and newly discovered phosphonic acid natural products. J. Antibiot. (Tokyo). https://doi.org/10.1038/ja.2015.77

8. Bolyen, E., Rideout, J.R., Dillon, M.R., Bokulich, N.A., Abnet, C.C., Al-Ghalith, G.A., Alexander, H., Alm, E.J., Arumugam, M., Asnicar, F., Bai, Y., Bisanz, J.E., Bittinger, K., Brejnrod, A., Brislawn, C.J., Brown, C.T., Callahan, B.J., Caraballo-Rodríguez, A.M., Chase, J., Cope, E.K., Da Silva, R., Diener, C., Dorrestein, P.C., Douglas, G.M., Durall, D.M., Duvallet, C., Edwardson, C.F., Ernst, M., Estaki, M., Fouquier, J., Gauglitz, J.M., Gibbons, S.M., Gibson, D.L., Gonzalez, A., Gorlick, K., Guo, J., Hillmann, B., Holmes, S., Holste, H., Huttenhower, C., Huttley, G.A., Janssen, S., Jarmusch, A.K., Jiang, L., Kaehler, B.D., Kang, K. Bin, Keefe, C.R., Keim, P., Kelley, S.T., Knights, D., Koester, I., Kosciolek, T., Kreps, J., Langille, M.G.I., Lee, J., Ley, R., Liu, Y.X., Loftfield, E., Lozupone, C., Maher, M., Marotz, C., Martin, B.D., McDonald, D., Mclver, L.J., Melnik, A. V., Metcalf, J.L., Morgan, S.C., Morton, J.T., Naimey, A.T., Navas-Molina, J.A., Nothias, L.F., Orchanian, S.B., Pearson, T., Peoples, S.L., Petras, D., Preuss, M.L., Pruesse, E., Rasmussen, L.B., Rivers, A., Robeson, M.S., Rosenthal, P., Segata, N., Shaffer, M., Shiffer, A., Sinha, R., Song, S.J., Spear, J.R., Swafford, A.D., Thompson, L.R., Torres, P.J., Trinh, P., Tripathi, A., Turnbaugh, P.J., Ul-Hasan, S., van der Hooft, J.J.J., Vargas, F., Vázquez-Baeza, Y., Vogtmann, E., von Hippel, M., Walters, W., Wan, Y., Wang, M., Warren, J., Weber, K.C., Williamson, C.H.D., Willis, A.D., Xu, Z.Z., Zaneveld, J.R., Zhang, Y., Zhu, Q., Knight, R., Caporaso, J.G., 2019. Reproducible, interactive, scalable and extensible microbiome data science using QIIME 2. Nat. Biotechnol. https://doi.org/10.1038/s41587-019-02099

9. Callahan, B.J., McMurdie, P.J., Rosen, M.J., Han, A.W., Johnson, A.J.A., Holmes, S.P., 2016. DADA2: High-resolution sample inference from Illumina amplicon data. Nat. Methods. https://doi.org/10.1038/nmeth.3869

10. Cantarel, B.I., Coutinho, P.M., Rancurel, C., Bernard, T., Lombard, V., Henrissat, B., 2009. The Carbohydrate-Active EnZymes database (CAZy): An expert resource for glycogenomics. Nucleic Acids Res. https://doi.org/10.1093/nar/gkn663

11. Ceccon, D.M., Faoro, H., Lana, P. da C., de Souza, E.M., Pedrosa, F. de O., 2019. Metataxonomic and metagenomic analysis of mangrove microbiomes reveals community patterns driven by salinity and 
pH gradients in Paranaguá Bay, Brazil. Sci. Total Environ.

https://doi.org/10.1016/j.scitotenv.2019.133609

12. ENGER, M.D., SLEEPER, B.P., 1965. MULTIPLE CELLULASE SYSTEM FROM STREPTOMYCES ANTIBIOTICUS. J. Bacteriol. https://doi.org/10.1002/path.1700890104

13. Ghashghavi, M., Hester, E.R., Oliver, V., Luke, C., Jetten, M.S.M., Lucker, S., 2019. Comparison of the bacterial and methanotrophic diversities between an Italian paddy field and its neighboring meadow. bioRxiv. https://doi.org/10.1101/535229

14. Green, M.R. (Michael R., Sambrook, J., Sambrook, J., 2012. Molecular cloning: a laboratory manual. Cold Spring Harbor Laboratory Press.

15. Huergo, L.F., Rissi, D. V., Elias, A.S., Gonçalves, M. V., Gernet, M. V., Barreto, F., Dahmer, G.W., Reis, R.A., Pedrosa, F.O., Souza, E.M., Monteiro, R.A., Baura, V.A., Balsanelli, E., Cruz, L.M., 2018. Influence of ancient anthropogenic activities on the mangrove soil microbiome. Sci. Total Environ. https://doi.org/10.1016/j.scitotenv.2018.07.094

16. Lim, J.H., Lee, C.R., Dhakshnamoorthy, V., Park, J.S., Hong, S.K., 2015. Molecular characterization of streptomyces coelicolor a(3) sco6548 as a cellulose 1,4-ß-cellobiosidase. FEMS Microbiol. Lett. https://doi.org/10.1093/femsle/fnv245

17. Liu, G., Chater, K.F., Chandra, G., Niu, G., Tan, H., 2013. Molecular Regulation of Antibiotic Biosynthesis in Streptomyces. Microbiol. Mol. Biol. Rev. https://doi.org/10.1128/mmbr.00054-12

18. M., I., R., K., 2020. Shotgun metagenomics reveals a heterogeneous prokaryotic community and a wide array of antibiotic resistance genes in mangrove sediment. FEMS Microbiol. Ecol.

19. Mendes, L.W., Tsai, S.M., 2018. Distinct taxonomic and functional composition of soil microbiomes along the gradient forest-restinga-mangrove in southeastern Brazil. Antonie van Leeuwenhoek, Int. J. Gen. Mol. Microbiol. https://doi.org/10.1007/s10482-017-0931-6

20. Nayfach, S., Roux, S., Seshadri, R., Udwary, D., Varghese, N., Schulz, F., Wu, D., Paez-Espino, D., Chen, I.M., Huntemann, M., Palaniappan, K., Ladau, J., Mukherjee, S., Reddy, T.B.K., Nielsen, T., Kirton, E., Faria, J.P., Edirisinghe, J.N., Henry, C.S., Jungbluth, S.P., Chivian, D., Dehal, P., Wood-Charlson, E.M., Arkin, A.P., Tringe, S.G., Visel, A., Abreu, H., Acinas, S.G., Allen, E., Allen, M.A., Andersen, G., Anesio, A.M., Attwood, G., Avila-Magaña, V., Badis, Y., Bailey, J., Baker, B., Baldrian, P., Barton, H.A., Beck, D.A.C., Becraft, E.D., Beller, H.R., Beman, J.M., Bernier-Latmani, R., Berry, T.D., Bertagnolli, A., Bertilsson, S., Bhatnagar, J.M., Bird, J.T., Blumer-Schuette, S.E., Bohannan, B., Borton, M.A., Brady, A., Brawley, S.H., Brodie, J., Brown, S., Brum, J.R., Brune, A., Bryant, D.A., Buchan, A., Buckley, D.H., Buongiorno, J., Cadillo-Quiroz, H., Caffrey, S.M., Campbell, A.N., Campbell, B., Carr, S., Carroll, J.L., Cary, S.C., Cates, A.M., Cattolico, R.A., Cavicchioli, R., Chistoserdova, L., Coleman, M.L., Constant, P., Conway, J.M., Mac Cormack, W.P., Crowe, S., Crump, B., Currie, C., Daly, R., Denef, V., Denman, S.E., Desta, A., Dionisi, H., Dodsworth, J., Dombrowski, N., Donohue, T., Dopson, M., Driscoll, T., Dunfield, P., Dupont, C.L., Dynarski, K.A., Edgcomb, V., Edwards, E.A., Elshahed, M.S., Figueroa, I., Flood, B., Fortney, N., Fortunato, C.S., Francis, C., Gachon, C.M.M., Garcia, S.L., Gazitua, M.C., Gentry, T., Gerwick, L., Gharechahi, J., Girguis, P., Gladden, J., Gradoville, M., Grasby, S.E., Gravuer, K., Grettenberger, C.L., 
Gruninger, R.J., Guo, J., Habteselassie, M.Y., Hallam, S.J., Hatzenpichler, R., Hausmann, B., Hazen, T.C., Hedlund, B., Henny, C., Herfort, L., Hernandez, M., Hershey, O.S., Hess, M., Hollister, E.B., Hug, L.A., Hunt, D., Jansson, J., Jarett, J., Kadnikov, V. V., Kelly, C., Kelly, R., Kelly, W., Kerfeld, C.A., Kimbrel, J., Klassen, J.L., Konstantinidis, K.T., Lee, L.L., Li, W.J., Loder, A.J., Loy, A., Lozada, M., MacGregor, B., Magnabosco, C., Maria da Silva, A., McKay, R.M., McMahon, K., McSweeney, C.S., Medina, M., Meredith, L., Mizzi, J., Mock, T., Momper, L., Moran, M.A., Morgan-Lang, C., Moser, D., Muyzer, G., Myrold, D., Nash, M., Nesbø, C.L., Neumann, A.P., Neumann, R.B., Noguera, D., Northen, T., Norton, J., Nowinski, B., Nüsslein, K., O’Malley, M.A., Oliveira, R.S., Maia de Oliveira, V., Onstott, T., Osvatic, J., Ouyang, Y., Pachiadaki, M., Parnell, J., Partida-Martinez, L.P., Peay, K.G., Pelletier, D., Peng, X., Pester, M., Pett-Ridge, J., Peura, S., Pjevac, P., Plominsky, A.M., Poehlein, A., Pope, P.B., Ravin, N., Redmond, M.C., Reiss, R., Rich, V., Rinke, C., Rodrigues, J.L.M., Rossmassler, K., Sackett, J., Salekdeh, G.H., Saleska, S., Scarborough, M., Schachtman, D., Schadt, C.W., Schrenk, M., Sczyrba, A., Sengupta, A., Setubal, J.C., Shade, A., Sharp, C., Sherman, D.H., Shubenkova, O. V., Sierra-Garcia, I.N., Simister, R., Simon, H., Sjöling, S., Slonczewski, J., Correa de Souza, R.S., Spear, J.R., Stegen, J.C., Stepanauskas, R., Stewart, F., Suen, G., Sullivan, M., Sumner, D., Swan, B.K., Swingley, W., Tarn, J., Taylor, G.T., Teeling, H., Tekere, M., Teske, A., Thomas, T., Thrash, C., Tiedje, J., Ting, C.S., Tully, B., Tyson, G., Ulloa, O., Valentine, D.L., Van Goethem, M.W., VanderGheynst, J., Verbeke, T.J., Vollmers, J., Vuillemin, A., Waldo, N.B., Walsh, D.A., Weimer, B.C., Whitman, T., van der Wielen, P., Wilkins, M., Williams, T.J., Woodcroft, B., Woolet, J., Wrighton, K., Ye, J., Young, E.B., Youssef, N.H., Yu, F.B., Zemskaya, T.I., Ziels, R., Woyke, T., Mouncey, N.J., Ivanova, N.N., Kyrpides, N.C., Eloe-Fadrosh, E.A., 2020. A genomic catalog of Earth's microbiomes. Nat. Biotechnol. https://doi.org/10.1038/s41587-020-0718-6

21. Overbeek, R., Olson, R., Pusch, G.D., Olsen, G.J., Davis, J.J., Disz, T., Edwards, R.A., Gerdes, S., Parrello, B., Shukla, M., Vonstein, V., Wattam, A.R., Xia, F., Stevens, R., 2014. The SEED and the Rapid Annotation of microbial genomes using Subsystems Technology (RAST). Nucleic Acids Res. https://doi.org/10.1093/nar/gkt1226

22. Pedregosa, F., Varoquaux, G., Gramfort, A., Michel, V., Thirion, B., Grisel, O., Blondel, M., Prettenhofer, P., Weiss, R., Dubourg, V., Vanderplas, J., Passos, A., Cournapeau, D., Brucher, M., Perrot, M., Duchesnay, É., 2011. Scikit-learn: Machine learning in Python. J. Mach. Learn. Res.

23. Pinheiro, G.L., de Azevedo-Martins, A.C., Albano, R.M., de Souza, W., Frases, S., 2017. Comprehensive analysis of the cellulolytic system reveals its potential for deconstruction of lignocellulosic biomass in a novel Streptomyces sp. Appl. Microbiol. Biotechnol. https://doi.org/10.1007/s00253-016-7851-7

24. Pylro, V., Roesch, L., 2017. The Brazilian microbiome project, in: The Brazilian Microbiome: Current Status and Perspectives. https://doi.org/10.1007/978-3-319-59997-7_1

25. Quast, C., Pruesse, E., Yilmaz, P., Gerken, J., Schweer, T., Yarza, P., Peplies, J., Glöckner, F.O., 2013. The SILVA ribosomal RNA gene database project: Improved data processing and web-based tools. Nucleic Acids Res. https://doi.org/10.1093/nar/gks1219

26. Reshetnikov, A.S., Khmelenina, V.N., Mustakhimov, I.I., Trotsenko, Y.A., 2011. Genes and enzymes of Ectoine biosynthesis in halotolerant methanotrophs, in: Methods in Enzymology.

https://doi.org/10.1016/B978-0-12-386905-0.00002-4

Page $14 / 21$ 
27. Seemann, T., 2014. Prokka: Rapid prokaryotic genome annotation. Bioinformatics. https://doi.org/10.1093/bioinformatics/btu153

28. Sharma, M., Jasrotia, S., Ohri, P., Manhas, R.K., 2019. Nematicidal potential of Streptomyces antibioticus strain $\mathrm{M7}$ against Meloidogyne incognita. AMB Express. https://doi.org/10.1186/s13568-019-0894-2

29. Souza, F.F.C., Rissi, D. V., Pedrosa, F.O., Souza, E.M., Baura, V.A., Monteiro, R.A., Balsanelli, E., Cruz, L.M., Souza, R.A.F., Andreae, M.O., Reis, R.A., Godoi, R.H.M., Huergo, L.F., 2019. Uncovering prokaryotic biodiversity within aerosols of the pristine Amazon forest. Sci. Total Environ. https://doi.org/10.1016/j.scitotenv.2019.06.218

30. Stets, M.I., Pinto, A.S., Huergo, L.F., de Souza, E.M., Guimarães, V.F., Alves, A.C., Steffens, M.B.R., Monteiro, R.A., Pedrosa, F.D.O., Cruz, L.M., 2013. Rapid identification of bacterial isolates from wheat roots by high resolution whole cell MALDI-TOF MS analysis. J. Biotechnol. 165. https://doi.org/10.1016/j.jbiotec.2013.04.001

31. Stevens, M.A., Riebesell, U., McDevitt-Irwin, J.M., Karlsson, R., Kanbar, J., Gifford, I., Clemente, J.C., Gong, D., Hasan, N.A., Ackermann, G., Okamoto, N., Munroe, P., Berry, A., Clayton, J.B., Jurburg, S.D., Stevens, R.L., Seyler, L.M., Orlando, L., González, A., Hidalgo, G., Hale, V., Tas, N., Gill, R.T., Hickman, J.E., Kueneman, J., Castellano, Y.O., Gerdts, G., Kling, G.W., Noyce, K., Morgan-Kiss, R.M., Michelangeli, F., Mason, O.U., Biddle, J.F., Siegel, J., Zhu, Q., Prill, R.J., Wang, S., Kosciolek, T., Dubinsky, E.A., Lipson, D.A., Jansson, J.K., Handley, K.M., Taylor, D.L., Coleman, M.L., Findlay, H.S., Neufeld, J.D., Fogliano, V., Dionisi, H.M., Ercolini, D., Tai, V., Amir, A., Kennedy, S.J., McMahon, K.D., Tait, K., Woodhams, D.C., Ni, Y., Bárta, J., Parnell, J., Friedman, E.S., Linz, A.M., Nolan, M.J., Hulth, S., Nicol, G.W., Braun, J., Defazio, J., van Zwieten, L., Willerslev, E., Shi, Y., McDonald, D., Cui, D., Hallam, S.J., Koehler, A. V., Scott, N.M., Richardson, M., Jex, A.R., Garcia-Amado, M.A., Rockne, K.J., Krezalek, M., Forsman, A., Werner, J.J., Giray, T., Webster, N.S., McKenzie, V., Minich, J., Gibbons, S.M., Bhatnagar, A., Pollock, F.J., Urich, T., Wood, S.A., Crump, B.C., Contreras, M., Freeman, C., Locey, K.J., Vitaglione, P., van der Lelie, D., Vargas-Robles, D., Thurber, R.V., Rohwer, F., Dominguez-Bello, M.G., Pfister, C., MacCormack, W.P., Ezenwa, V., Antonopoulos, D.A., Seger, R.L., Chu, H., Andras, J., Grossart, H.-P., Liu, Y., Bokulich, N.A., Caporaso, J.G., Soler, J.J., Pilon-Smits, E., Johnston, E.R., Boldgiv, B., Kerkhof, L.J., Ballantine, K., Shogan, B.D., Sanz, V., Gilbert, J.A., Jurelevicius, D., Hall, R.S., Gittel, A., Ibáñez-Álamo, J.D., Goodwin, K.D., Charles, T.C., Bhatnagar, M., Campbell, A.H., Martín-Vivaldi, M., Stephens, B., Schrenzel, M.D., Prithiviraj, B., Navas-Molina, J.A., Rao, S., Hyde, E., Gibson, M.K., Amato, K.R., Crary, B.B., SeguinOrlando, A., Timling, I., Marzinelli, E.M., Rees, A.P., McDonald, J.E., Simmons, S., Clark, R.G., Clauset, A., Golyshin, P., Vázquez-Baeza, Y., Humphrey, G., Mills, D.A., Taghavi, S., Moitinho-Silva, L., Cardona, C., Safran, R.J., Owens, S.M., Hampton-Marcell, J., Boyer, D.M., Bittner, L., Gasser, R.B., Weiss, S., Ladau, J., Seldin, L., Carroll, J., Brislawn, C.J., Cary, S.C., Haig, S.-J., Spirito, C.M., Johnson, L.S., Oswald, W., Ranjan, R., Van Treuren, W., Baum, J.K., Claar, D.C., Meyer, F., Haroon, M.F., Kauppinen, S., Bottos, E., Daly, S.E., Dawson, R.D., Sperling, M., Miller, K., Joseph, S., Kopylova, E., Lozada, M., Landon, E.M., Peralta-Sánchez, J.M., Lamendella, R., Medina, M., Rodriguezl, S.M., Turner, B.L., Shin, H., MacRae-Crerar, A., Zaneveld, J., Piombino, P., West, K., Larsen, P., Janssen, S., Tan, C.L., Berg- 
Lyons, D., Wang, T., Mocali, S., O’Brien, S.L., Nielsen, S., Galindo, G., Fierer, N., Sangwan, N., Cochran, A., McMinds, R., Brazelton, W., Fuhrman, J.A., Wehrle, B., Weisenhorn, P., Robinson, C., Guyton, K., Thompson, L.R., Hofmockel, K.S., Liancourt, P., Angenent, L.T., King, G.M., Weaver, T., Whitehead, A., Mayer, G.D., Yang, Y., Collins, G., Myrold, D., Martínez, L.M., Thomas, T., Lane-deGraaf, K., Laverock, B., Walker, D.A., Sanders, J.G., Tripathi, A., Dunn, P.O., Potter, C., Martínez-Bueno, M., Apprill, A., Shade, A., Zarraonaindia, I., Lefler, J., LaRoche, J., Fleming, I.D., Lax, S., Petraitis, P., Jin Song, S., Nissimov, J.I., Espinoza, R.E., Hultman, J., Cristol, D.A., Davalos, L., Magris, M., Hooker, J., Shen, C., Haydon, S.R., Jastrow, J.D., Zhao, H., Sjöling, S., Casper, B.B., Delsuc, F., Osuolale, O., Whittingham, L.A., Mendelson, J.R., Ursell, L.K., Sheets, G.M., McGuire, K.L., Lladser, M.E., Jiang, L., Steinberg, P.D., Dowell, R., Armitage, D., Mirarab, S., Knight, R., Kellogg, C.T.E., Smith, D.P., Shakhsheer, B., Rani, A., Colwell, R.R., Garshelis, D., Lentino, M., Creer, S., Zhang, Q., Fenner, N., Quince, C., Williams, A.E., Zech Xu, Z., Metcalf, J.L., Brearley, F.Q., Pointing, S.B., Walters, W.A., Garcia, L., Niu, K., Karlsson, A., Alverdy, J., Schrenk, M., Pollard, K.S., Whitehead, S.R., Morton, J.T., Moore, A., Al-Moosawi, L., Martín-Platero, A.M., Roundstone, W., Rivera, J.L.A., Liang, W., Shutler, D., Levin, I.I., 2017. A communal catalogue reveals Earth's multiscale microbial diversity. Nature. https://doi.org/10.1038/nature24621

32. Takasuka, T.E., Book, A.J., Lewin, G.R., Currie, C.R., Fox, B.G., 2013. Aerobic deconstruction of cellulosic biomass by an insect-associated Streptomyces. Sci. Rep.

https://doi.org/10.1038/srep01030

33. Thompson, L.R., Sanders, J.G., McDonald, D., Amir, A., Ladau, J., Locey, K.J., Prill, R.J., Tripathi, A., Gibbons, S.M., Ackermann, G., Navas-Molina, J.A., Janssen, S., Kopylova, E., Vázquez-Baeza, Y., González, A., Morton, J.T., Mirarab, S., Xu, Z.Z., Jiang, L., Haroon, M.F., Kanbar, J., Zhu, Q., Song, S.J., Kosciolek, T., Bokulich, N.A., Lefler, J., Brislawn, C.J., Humphrey, G., Owens, S.M., Hampton-Marcell, J., Berg-Lyons, D., McKenzie, V., Fierer, N., Fuhrman, J.A., Clauset, A., Stevens, R.L., Shade, A., Pollard, K.S., Goodwin, K.D., Jansson, J.K., Gilbert, J.A., Knight, R., Agosto Rivera, J.L., Al-Moosawi, L., Alverdy, J., Amato, K.R., Andras, J., Angenent, L.T., Antonopoulos, D.A., Apprill, A., Armitage, D., Ballantine, K., Bárta, J., Baum, J.K., Berry, A., Bhatnagar, A., Bhatnagar, M., Biddle, J.F., Bittner, L., Boldgiv, B., Bottos, E., Boyer, D.M., Braun, J., Brazelton, W., Brearley, F.Q., Campbell, A.H., Caporaso, J.G., Cardona, C., Carroll, J.L., Cary, S.C., Casper, B.B., Charles, T.C., Chu, H., Claar, D.C., Clark, R.G., Clayton, J.B., Clemente, J.C., Cochran, A., Coleman, M.L., Collins, G., Colwell, R.R., Contreras, M., Crary, B.B., Creer, S., Cristol, D.A., Crump, B.C., Cui, D., Daly, S.E., Davalos, L., Dawson, R.D., Defazio, J., Delsuc, F., Dionisi, H.M., Dominguez-Bello, M.G., Dowell, R., Dubinsky, E.A., Dunn, P.O., Ercolini, D., Espinoza, R.E., Ezenwa, V., Fenner, N., Findlay, H.S., Fleming, I.D., Fogliano, V., Forsman, A., Freeman, C., Friedman, E.S., Galindo, G., Garcia, L., Garcia-Amado, M.A., Garshelis, D., Gasser, R.B., Gerdts, G., Gibson, M.K., Gifford, I., Gill, R.T., Giray, T., Gittel, A., Golyshin, P., Gong, D., Grossart, H.P., Guyton, K., Haig, S.J., Hale, V., Hall, R.S., Hallam, S.J., Handley, K.M., Hasan, N.A., Haydon, S.R., Hickman, J.E., Hidalgo, G., Hofmockel, K.S., Hooker, J., Hulth, S., Hultman, J., Hyde, E., Ibáñez-Álamo, J.D., Jastrow, J.D., Jex, A.R., Johnson, L.S., Johnston, E.R., Joseph, S., Jurburg, S.D., Jurelevicius, D., Karlsson, A., Karlsson, R., Kauppinen, S., Kellogg, C.T.E., Kennedy, S.J., Kerkhof, L.J., King, G.M., Kling, G.W., Koehler, A. V., Krezalek, M., Kueneman, J., Lamendella, R., Landon, E.M., Lanede Graaf, K., LaRoche, J., Larsen, P., Laverock, B., Lax, S., Lentino, M., Levin, I.I., Liancourt, P., Liang, W., Linz, A.M., Lipson, D.A., Liu, Y., 
Lladser, M.E., Lozada, M., Spirito, C.M., MacCormack, W.P., MacRae-Crerar, A., Magris, M., MartínPlatero, A.M., Martín-Vivaldi, M., Martínez, L.M., Martínez-Bueno, M., Marzinelli, E.M., Mason, O.U., Mayer, G.D., McDevitt-Irwin, J.M., McDonald, J.E., McGuire, K.L., McMahon, K.D., McMinds, R., Medina, M., Mendelson, J.R., Metcalf, J.L., Meyer, F., Michelangeli, F., Miller, K., Mills, D.A., Minich, J., Mocali, S., Moitinho-Silva, L., Moore, A., Morgan-Kiss, R.M., Munroe, P., Myrold, D., Neufeld, J.D., Ni, Y., Nicol, G.W., Nielsen, S., Nissimov, J.I., Niu, K., Nolan, M.J., Noyce, K., O’Brien, S.L., Okamoto, N., Orlando, L., Castellano, Y.O., Osuolale, O., Oswald, W., Parnell, J., Peralta-Sánchez, J.M., Petraitis, P., Pfister, C., Pilon-Smits, E., Piombino, P., Pointing, S.B., Pollock, F.J., Potter, C., Prithiviraj, B., Quince, C., Rani, A., Ranjan, R., Rao, S., Rees, A.P., Richardson, M., Riebesell, U., Robinson, C., Rockne, K.J., Rodriguezl, S.M., Rohwer, F., Roundstone, W., Safran, R.J., Sangwan, N., Sanz, V., Schrenk, M., Schrenzel, M.D., Scott, N.M., Seger, R.L., Seguinorlando, A., Seldin, L., Seyler, L.M., Shakhsheer, B., Sheets, G.M., Shen, C., Shi, Y., Shin, H., Shogan, B.D., Shutler, D., Siegel, J., Simmons, S., Sjöling, S., Smith, D.P., Soler, J.J., Sperling, M., Steinberg, P.D., Stephens, B., Stevens, M.A., Taghavi, S., Tai, V., Tait, K., Tan, C.L., Taş, N., Taylor, D.L., Thomas, T., Timling, I., Turner, B.L., Urich, T., Ursell, L.K., Van Der Lelie, D., Van Treuren, W., Van Zwieten, L., Vargas-Robles, D., Thurber, R.V., Vitaglione, P., Walker, D.A., Walters, W.A., Wang, S., Wang, T., Weaver, T., Webster, N.S., Wehrle, B., Weisenhorn, P., Weiss, S., Werner, J.J., West, K., Whitehead, A., Whitehead, S.R., Whittingham, L.A., Willerslev, E., Williams, A.E., Wood, S.A., Woodhams, D.C., Yang, Y., Zaneveld, J., Zarraonaindia, I., Zhang, Q., Zhao, H., 2017. A communal catalogue reveals Earth's multiscale microbial diversity. Nature. https://doi.org/10.1038/nature24621

34. Waksman, S.A., Woodruff, H.B., 1941. Actinomyces antibioticus, a New Soil Organism Antagonistic to Pathogenic and Non-pathogenic Bacteria 1. J. Bacteriol. https://doi.org/10.1128/jb.42.2.231249.1941

35. Wang, F., Fu, S.N., Bao, Y.X., Yang, Y., Shen, H.F., Lin, B.R., Zhou, G.X., 2017. Kitamycin C, a new antimycin-type antibiotic from Streptomyces antibioticus strain 200-09. Nat. Prod. Res. https://doi.org/10.1080/14786419.2017.1295240

36. Wilson, M.C., Mori, T., Rückert, C., Uria, A.R., Helf, M.J., Takada, K., Gernert, C., Steffens, U.A.E., Heycke, N., Schmitt, S., Rinke, C., Helfrich, E.J.N., Brachmann, A.O., Gurgui, C., Wakimoto, T., Kracht, M., Crüsemann, M., Hentschel, U., Abe, I., Matsunaga, S., Kalinowski, J., Takeyama, H., Piel, J., 2014. An environmental bacterial taxon with a large and distinct metabolic repertoire. Nature. https://doi.org/10.1038/nature12959

37. Xu, L.Y., Quan, X.S., Wang, C., Sheng, H.F., Zhou, G.X., Lin, B.R., Jiang, R.W., Yao, X.S., 2011. Antimycins A 19 and A 20, two new antimycins produced by marine actinomycete Streptomyces antibioticus H74-18. J. Antibiot. (Tokyo). https://doi.org/10.1038/ja.2011.65

\section{Figures}


A

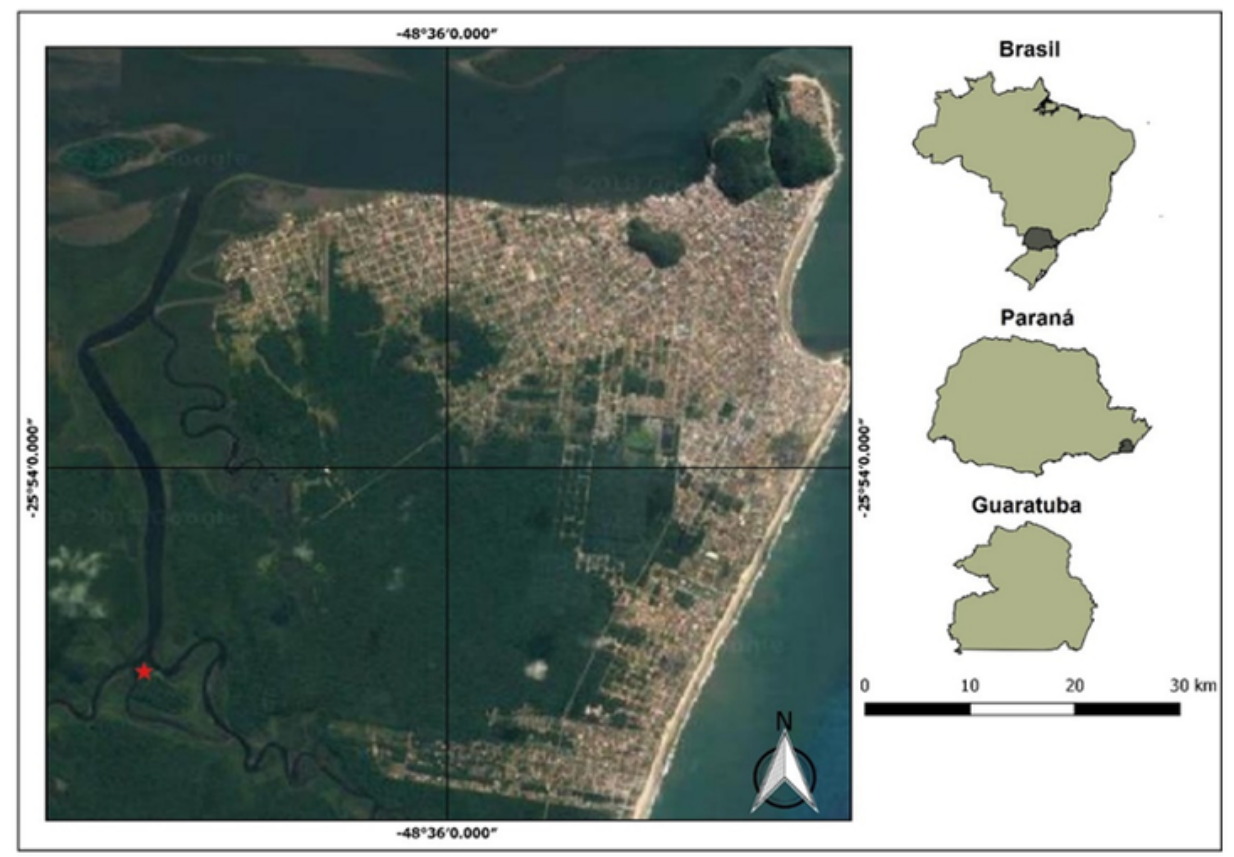

B
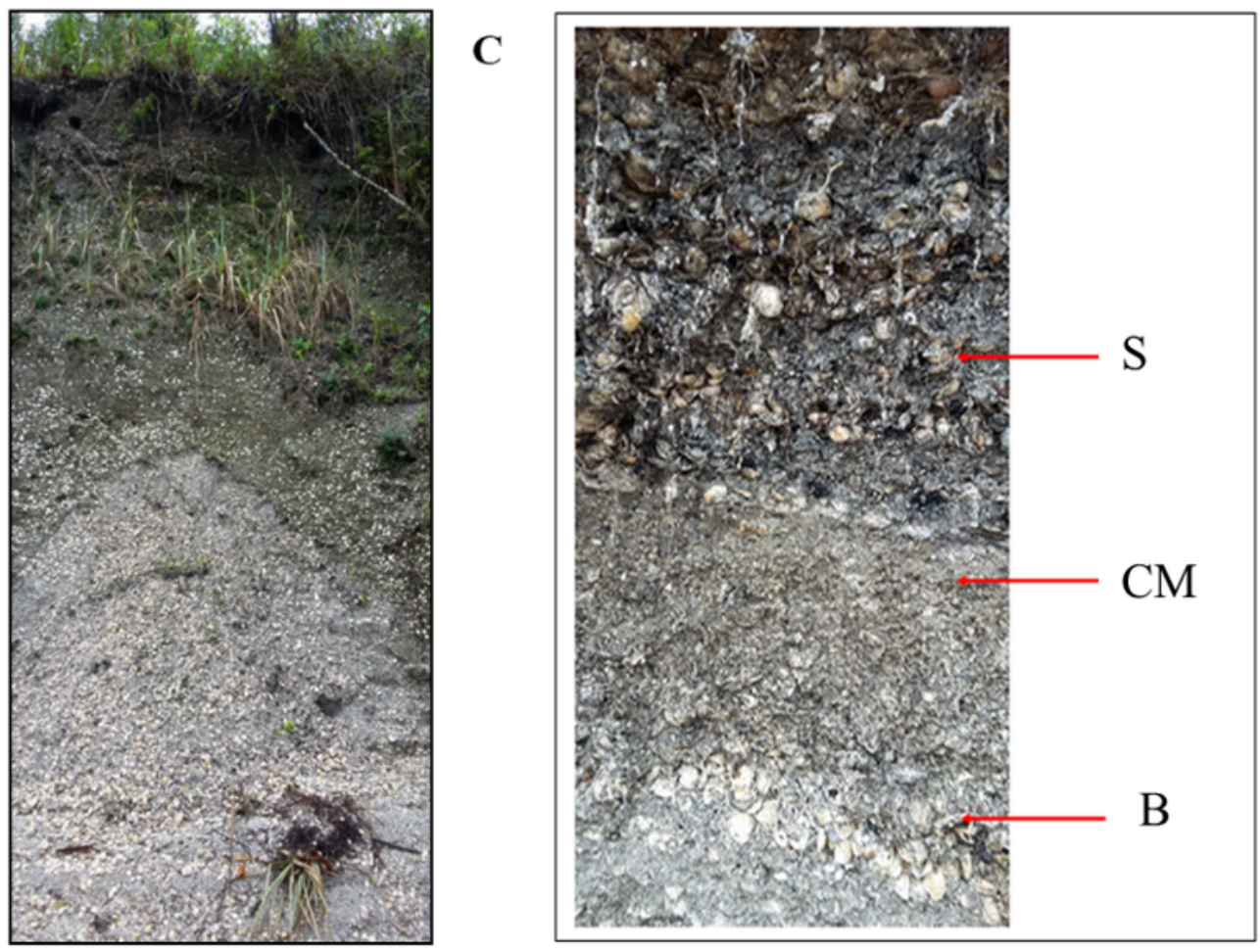

\section{Figure 1}

Location of the collection site. A) Satellite Image of Guaratuba-PR, Brazil. The red dot indicates the Sambaqui located at the margin of the Boguaçú river. B) Photograph of the Samabaqui site taken from the Boguaçú river. The top is $7 \mathrm{~m}$ high from the river level. C) Different layers of shell debris that represent the chronological history of the Sambaqui site. The arrows indicate the different layers that were sampled and coded as: B, CM and S 


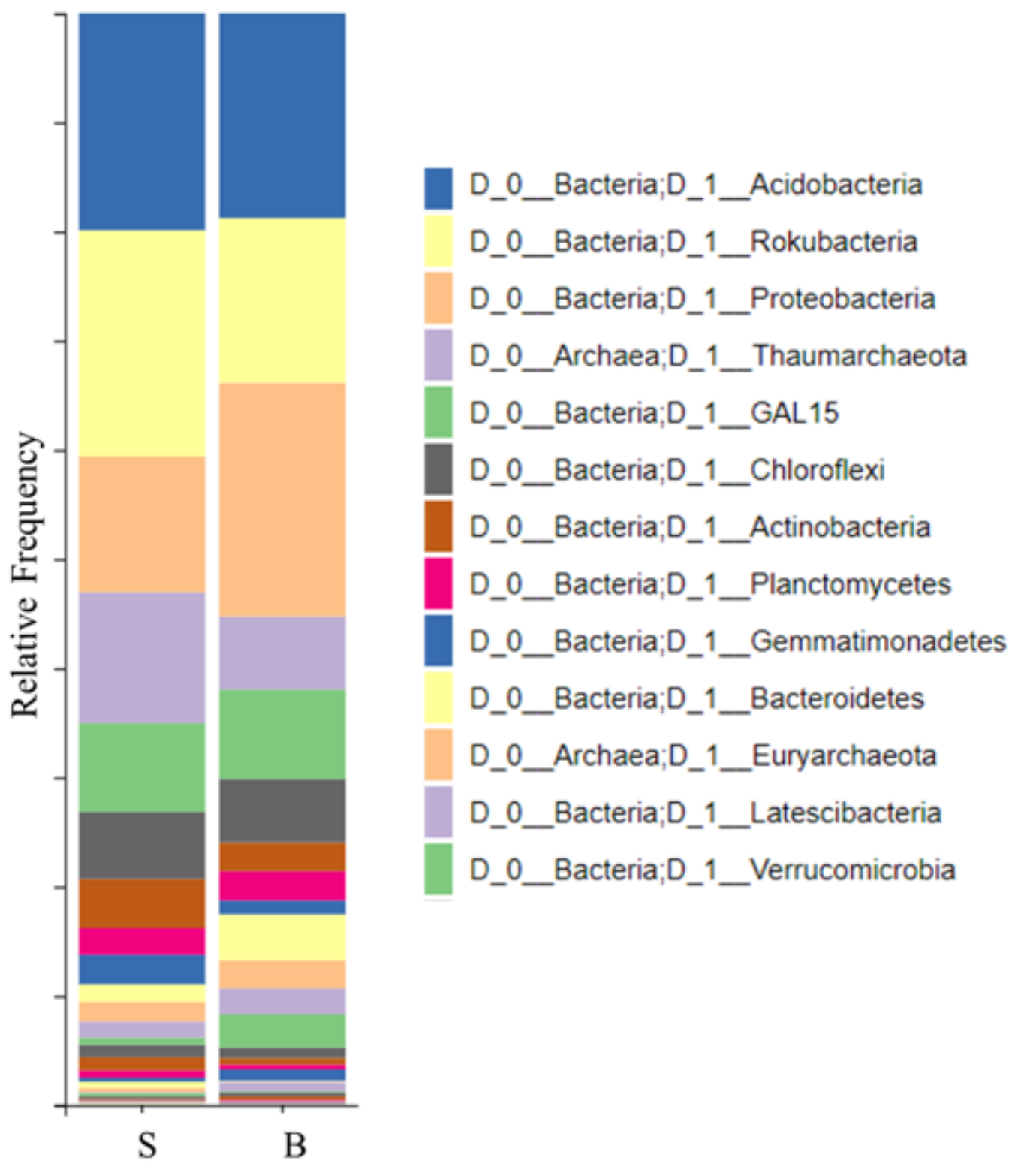

Figure 2

Microbial taxonomical distribution at phylum level of the $S$ and B samples from Boguaçú Sambaqui, based on metagenome 16S rDNA amplicon sequencing. The figure was generated using QUIIME2. 

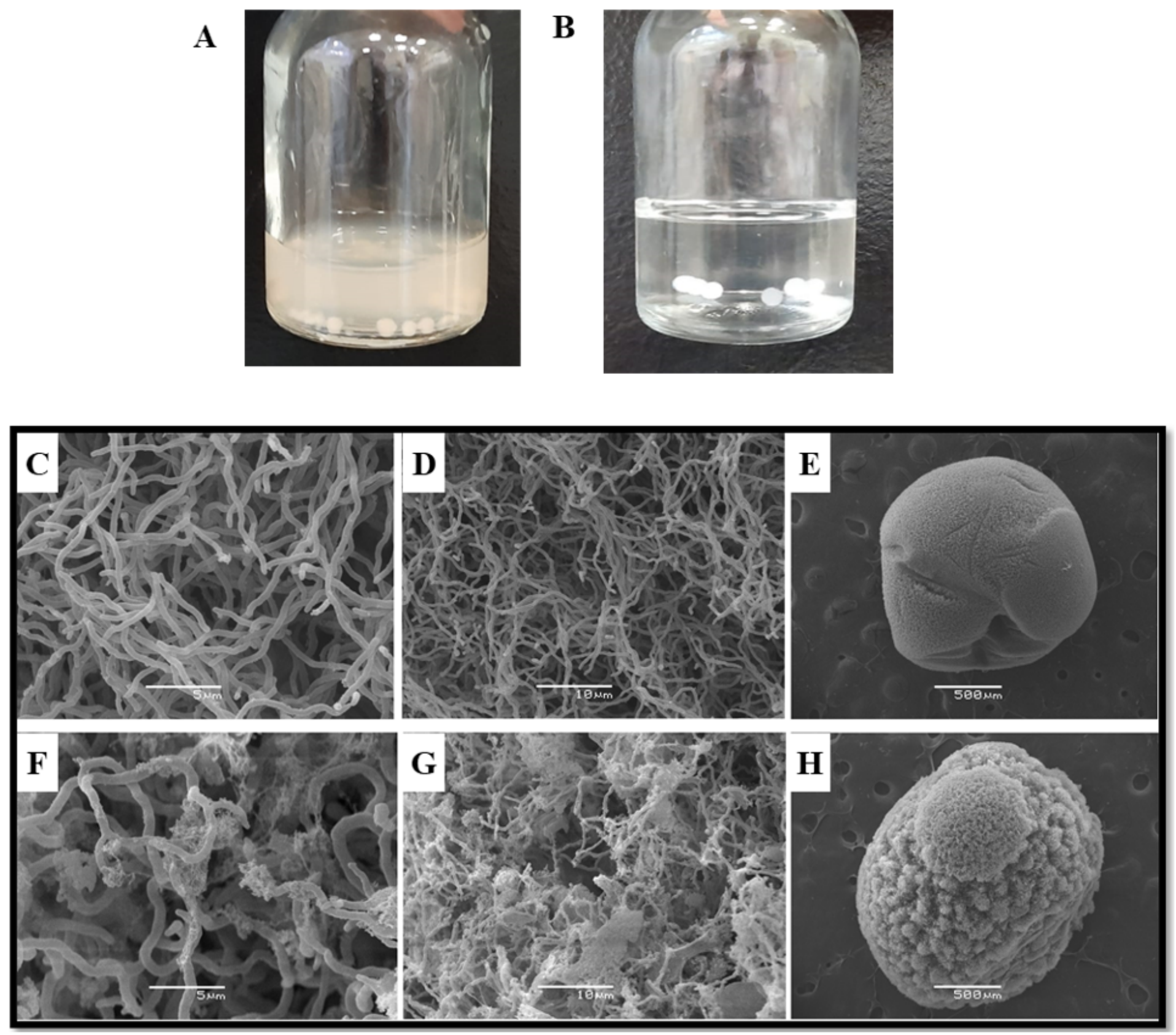

Figure 3

Morphological characterization of Streptomyces sp. S3. Cells were cultured in liquid M9 medium containing: A) xylan ; B) CMC, as carbon source. The cell pellets were analyzed by scanning electron microscopy. The imagens in $C, D$ and $E$ are cells grown in xylan at 5, 10 and $500 \mu \mathrm{m}$ magnification. The imagens in $\mathrm{F}, \mathrm{G}$ and $\mathrm{H}$ are cells grown in $\mathrm{CMC}$ at 5,10 and $500 \mu \mathrm{m}$ magnification.

\section{Supplementary Files}

This is a list of supplementary files associated with this preprint. Click to download. 
- tableS1.xIsx

- Tables2.xlsx

- tableS3.xlsx

- figS6.pdf

- Fig.S7genomicblastS3tree.pdf

- figuressuppsamabaqui.pptx 